\title{
Adsorptive study of coagulation treatment of paint wastewater using novel Brachystegia eurycoma extract
}

\author{
M. C. Menkiti ${ }^{1,2} \cdot$ A. O. Okoani ${ }^{2,3}$ (1) M. I. Ejimofor ${ }^{2}$
}

Received: 25 April 2017 / Accepted: 23 September 2018 / Published online: 3 October 2018

(c) The Author(s) 2018

\begin{abstract}
Adsorptive component of coagulation-flocculation of paint wastewater using Brachystegia eurycoma (seed) coagulant was investigated. The bio-sample was analyzed for functional groups, surface morphology and thermal characteristics. The effects of coagulant dosage, effluent $\mathrm{pH}$ and settling time on the process were studied. The coagulation data were analyzed in light of adsorption kinetics, isotherm and thermodynamics. Pseudo-second-order and Langmuir models best described the models, and the values recorded for Gibb's free energy, entropy and enthalpy values were-28.692 kJ/mol, $0.206 \mathrm{~kJ} /$ $\mathrm{mol}$ and $34.857 \mathrm{~kJ} / \mathrm{mol}$, respectively. At the experimental condition, maximum process efficiency $(96.50 \%)$ was obtained at coagulant dosage of $5 \mathrm{~g} / \mathrm{L}, \mathrm{pH} 8$ and coagulation temperature of $35^{\circ} \mathrm{C}$. Having satisfactorily correlated coagulation data to adsorption models, it could be inferred that significant component of the process was predominated by adsorption.
\end{abstract}

Keywords Brachystegia eurycoma $\cdot$ Paint wastewater $\cdot$ Flocculation $\cdot$ Coagulation $\cdot$ Adsorption kinetics

\section{List of symbols}

\begin{tabular}{|c|c|}
\hline AAS & Atomic absorption spectroscopy \\
\hline $\mathrm{BEC}$ & Brachystegia eurycoma coagulant \\
\hline $\mathrm{BEF}$ & Brachystegia eurycoma seed flour \\
\hline BECPWW & $\begin{array}{l}\text { Brachystegia eurycoma coagulant in paint } \\
\text { wastewater }\end{array}$ \\
\hline$D_{\mathrm{F}}$ & Film diffusion coefficient \\
\hline$D_{\mathrm{P}}$ & Intra-particle diffusion coefficient \\
\hline DSC & Differential scanning calorimetry \\
\hline$E_{\mathrm{a}}$ & Activation energy \\
\hline FTIR & Fourier transform infrared \\
\hline$K_{1}, K_{2}$ & $\begin{array}{l}\text { Coagulation kinetic rate for reversible first } \\
\text { order and pseudo-second order }\end{array}$ \\
\hline$K_{\mathrm{F}}, K_{\mathrm{L}}, K_{\mathrm{T}}$ & $\begin{array}{l}\text { Isotherm constants for Freundlich, Langmuir } \\
\text { and Temkin }\end{array}$ \\
\hline$K_{\text {id }}$ & $\begin{array}{l}\text { Intra-particle diffusion coagulation kinetic } \\
\text { rate }\end{array}$ \\
\hline
\end{tabular}

M. C. Menkiti

cmenkiti@yahoo.com; matthew.menkiti@ttu.edu

1 Civil and Environmental Engineering Department, Water Resources Center, Texas Tech University, Lubbock, TX, USA

2 Chemical Engineering Department, Nnamdi Azikiwe University, Awka, Nigeria

3 Department of Mechanical Engineering, University of Nigeria, Nsukka, Enugu, Nigeria

$\begin{array}{ll}\text { NTU } & \text { Nephelometric turbidity units } \\ q_{\mathrm{e}} & \text { Adsorption capacity at equilibrium } \\ q_{t} & \text { Adsorption capacity at time, } t \\ R^{2} & \text { Correlation/regression coefficient } \\ \text { SEM } & \text { Scanning electron spectroscopy } \\ \text { SSE } & \text { Sum of square error }(\%) \\ T & \text { Reaction temperature } \\ T_{i} & \text { Initial turbidity of solution, NTU } \\ T_{o} & \text { Final turbidity of solution, NTU } \\ \text { TDSP } & \text { Total dissolved and suspended particles } \\ \text { TGA } & \text { Thermo-gravimetric analysis } \\ \text { TS } & \text { Total solids } \\ \text { TSS } & \text { Total suspended solids } \\ 1^{\circ} & \text { Primary } \\ 2^{\circ} & \text { Secondary }\end{array}$

\section{Introduction}

Paint production is currently one of the major viable small and medium scale enterprises (SMEs) in Nigeria. However, the wastewater generated from the plant has aroused considerable interest in the scientific community (da Silva et al. 2016) and poses great threat to the environment if not properly treated prior to its discharge. This is due to the high quantity of different harmful chemical compounds used in paint production. These chemicals are mainly inorganic 
substances with high polar and hydrophilic functional groups (Madukasi et al. 2009). From the literature, the characterization results of paint wastewater indicate that they are nonbiodegradable with chemical oxygen demand (COD) and suspended solids (SS). Also, da Silva et al. (2016) have it that the wastewater presents high coloration, turbidity, strong odor and contain high loads of organic and toxic chemical substances, such as surfactants, bactericides, oils, solvents and preservative agents. There are also traces of some elements such as mercury, copper, chromium, zinc, iron, lead and coloring agents (Madukasi et al. 2009; Aboulhassan et al. 2014). The release of the wastewater directly into water bodies can constitute to ecological instability, since the presence of color blocks the passage of sunlight, thereby preventing the photosynthesis of aquatic plants, which in turn leads to the depletion of dissolved oxygen (da Silva et al. 2016). Therefore, there is need to reduce their concentrations (specifically, the particles in this study) to acceptable standards before discharging into the environment (Simate et al. 2012).

Over the years, several researchers have employed different technologies like adsorption, ion exchange, electrochemical, filtration, ultrafiltration, sedimentation, reverse osmosis and coagulation-flocculation in the treatment of organic or inorganic industrial wastewater (Santos et al. 2012; Muruganandam et al. 2017). Nevertheless, coagulation-flocculation technique has remained a more preferred initial treatment method for the removal of colloidal, suspended materials and organic matter that remain dispersed in the solution (da Silva et al. 2016; Suidan 1998; Diterlizzi 1994). Coagulation/flocculation simply entails the addition of coagulant/flocculant to allow destabilization of colloidal particles in suspension due to neutralization of negative charges, thereby facilitating formation of precipitable/settleable flocs and favoring a considerable increase in sedimentation rate. These destabilized particles collide, thereby forming larger particles that settle at the bottom, which can be removed by sedimentation, flotation or filtration (Diaz et al. 2018; Zeng and Park 2009; da Silva et al. 2016). A series of steps are involved in coagulation, including the electrostatic attraction between cationic proteins and negatively charged suspended impurities, followed by the destabilization of particles. The mechanisms exhibited by coagulation/flocculation in the removal of dissolved and particulate contaminants include: charge neutralization, adsorption, sweeping and bridge formation, precipitative coagulation and electrostatic patch (Muruganandam et al. 2017; Kumar et al. 2016; Santos et al. 2012). The conventional coagulants often adopted for wastewater treatment are inorganic salts of iron and aluminum (Zeng and park 2009). These include alum, ferric chloride, calcium hydroxide, sodium aluminate, aluminum chloride and ferric sulfate. These salts have been used for years because of their proven performance and ease of handling (Amirtharajah and
Mills 1982). However, the applications of the salts have several serious drawbacks such as: Alzheimer's disease causativeness, reduction in treated water $\mathrm{pH}$ due to the reaction between alum and natural water alkaline. Other drawbacks include: inherent, strong hydrolysis properties of $\mathrm{Fe}^{3+}$ limiting polymerization of Fe-based coagulants, low coagulation efficiency in cold water, non-biodegradability and high sludge generation (Mohammed et al. 2012; Ani et al. 2011).

In light of the above, the need to ameliorate the harmful effects of these salts through the use of alternative greener and sustainable approach makes the use of natural coagulants or bio-extracts imperative (Maurya and Daverey 2018). Such bio-extracts are sourced from animals and plants that are generally health and environmental friendly, biodegradable, non-toxic, non-corrosive and of low sludge volume (Maurya and Daverey 2018; Vijayaraghavan et al. 2011; Yin 2010). Maurya and Daverey 2018 in their study further stated that natural coagulants from plant-based materials or renewable sources are attracting a lot of attention due to their various advantages over the inorganic coagulants. A number of previous studies have been reported elsewhere on the treatment of industrial wastewater using these natural coagulants (Ani et al. 2011; Menkiti et al. 2011; Simate et al. 2012; Muruganandam et al. 2017).

In this present study, the focus is on Brachystegia eurycoma seed, a precursor to Brachystegia eurycoma coagulant (BEC). The seed belongs to caesalpiniaceae family and order of fabaceae with $56 \%$ carbohydrate, $15 \%$ crude fat, $9 \%$ protein, $4.5 \%$ ash and $2.9 \%$ crude fiber (Aviara et al. 2014) This work investigates the novel application of BEC for the effective coagulation-flocculation treatment of paint wastewater (PWW) following its coagulation property. According to Kumar et al. (2016), coagulation using natural coagulants is one of the recently used methods in industrial wastewater treatment plants. Since they produce lesser sludge with high nutritional value, the sludge handling and treatment cost is minimal (Maurya and Daverey 2018; Ndukwu 2009; Ikegwu et al. 2010; Ezeagu et al. 2006; Santos et al. 2012; Choudhary and Neogi 2017).

However, coagulation-flocculation treatment process is predominated by particles aggregation that could be driven by adsorption or non-adsorption. Adsorption is a well-known surface phenomenon in which solute/particles in a given medium are physically or chemically adhered to the surface of solid matrix to achieve materials separation (Narayana 2012; Jatto 2010). Currently, there exist significant studies deficit on adsorptive component of bio-coagulation. This gap is what this work attempts to close. Hence, the study is of coagulation-flocculation process in light of adsorption kinetics, isotherm and thermodynamics. Furthermore, the work aims to investigate the effect of selected process variables (coagulant dosage, effluent $\mathrm{pH}$, coagulation temperature and settling time) on treatment efficiency of PWW. 


\section{Materials and methods}

\section{Materials collection and preparation}

\section{Paint wastewater (PWW) sample}

The PWW sample was collected at batch production wash-off from a paint factory in Enugu State, Nigeria. The waste sample was preserved in amber colored gallons immersed in drums of water with ice blocks to prevent photo-catalyzed changes in the effluent composition.

\section{Brachystegia eurycoma seeds sample}

Brachystegia eurycoma seeds which served as the precursor for the preparation of BEC were sourced from Nkanu west in Enugu State, Nigeria. The seeds obtained by breaking the pods were sun-dried for 3 days and then stored in well-ventilated jute sack. Subsequently, $300 \mathrm{~g}$ of the Brachystegia eurycoma seeds were machine-milled and plate-sieved to obtain seed flour of 0.5-0.6-mm particle size (Adebowale and Adebowale 2007; Aviara, et al. 2014). The Brachystegia eurycoma seed flour (BEF) was stored in a dry ventilated container for further use.

\section{Extraction of BEC}

BEC extraction was based on modified report of Sutherland (2005). In this report, $250 \mathrm{~g}$ of the BEF was initially soaked in excess ethanol while being stirred continuously for $90 \mathrm{~min}$, after which the mixture was filtered with Whatman filter paper no. 3 . The filtration residue was poured into a container containing multiple salts solution. This salts solution contain a mixture of aqueous solutions of calcium chloride $(0.7 \mathrm{~g} / \mathrm{L})$, magnesium chloride $(4 \mathrm{~g} / \mathrm{L})$, potassium chloride $(0.75 \mathrm{~g} / \mathrm{L})$ and sodium chloride $(30 \mathrm{~g} / \mathrm{L})$ in the ratio of $1: 10(\mathrm{w} / \mathrm{v})$ (solid-solution ratio). The mixture was placed on a magnetic stirrer, stirred continuously for $1 \mathrm{~h}$ and subsequently filtered with Whatman filter paper to remove the spent solid. The resulting filtrate was poured into a well-stirred beaker and firstly heated to a constant temperature of $70^{\circ} \mathrm{C}$. The heating (at $70{ }^{\circ} \mathrm{C}$ ) was held for 1 min to set up precipitation of desired BEC out of the filtrate solution. The precipitate (BEC) was separated from the remaining liquid filtrate. Finally, the produced BEC was dried, pulverized and stored in airtight container for further use.

\section{Characterization of samples}

\section{Paint wastewater (PWW) sample}

PWW quality parameters (TSS, TDS, TS, turbidity, $\mathrm{pH}$ and conductivity) as listed in Table 1 were measured in line with
Table 1 Characteristics of paint wastewater (PWW) characterization

\begin{tabular}{ll}
\hline Parameter & Content \\
\hline Total suspended solids (TSS) $(\mathrm{mg} / \mathrm{L})$ & 2690 \\
Total dissolved solids (TDS) $(\mathrm{mg} / \mathrm{L})$ & 1320 \\
Total solids $(\mathrm{TS})(\mathrm{mg} / \mathrm{L})$ & 4010 \\
Initial turbidity $(\mathrm{NTU})$ & 1706.5 \\
$\mathrm{pH}$ & 8.0 \\
Conductivity $\left(\mu \mathrm{s} / \mathrm{cm}^{2}\right)$ & 1.53 \\
\hline
\end{tabular}

Table 2 Physicochemical characteristics of Brachystegia eurycoma precursor sample

\begin{tabular}{ll}
\hline Components & Content (\%) \\
\hline Yield (\%) & 90 \\
Weight loss (\%) & 8 \\
Bulk density (g/mL) & 0.45 \\
Moisture content (\%) & 14.5 \\
Ash content (\%) & 13 \\
Oil content (\%) & 11 \\
Protein $(\%)$ & 21 \\
\hline
\end{tabular}

American Public Health Association (APHA) standard for the examination of water and wastewater (Wennie et al. 2014; CCME 2008; Freese et al. 2003 and APHA 2012).

\section{Brachystegia eurycoma sample}

The proximate analysis (Table 2) on the seed sample was performed according to the procedures reported by Kyzas and Delitanni (2015), AOAC (2012), AFIA (2011) and Ani et al. (2011).

Determination of percentage yield and weight loss Two hundred and fifty grams of BEF was processed into BEC of weight A as described in "Extraction of BEC" section. The yield and weight loss are expressed as Eqs. 1 and 2, respectively.

Yield $(\%)=\frac{A}{250} \times 100$

Weight loss $(\%)=\frac{250-A}{250} \times 100$

Determination of bulk density Thirty-five grams of BEF was used to fill up 100-mL container, and the bulk density was calculated using the following:

Bulk density $=\frac{W}{V}$ 
where $W$ is weight of $\mathrm{BEF}(\mathrm{g})$ and $V$ is volume of the container $(\mathrm{mL})$.

Determination of percentage moisture content Two grams of BEF was weighed into pre-weighed crucible. The crucible and the content were weighed again and inserted into an oven set at $150{ }^{\circ} \mathrm{C}$ for $5 \mathrm{~h}$, after which it was removed, cooled and re-weighed. Equation 4 calculates moisture content.

Moisture content $(\%)=\frac{W_{\text {sample }}-W_{\text {dry }}}{W_{\text {sample }}} \times 100$

where $W_{\text {sample }}$ is weight of sample before drying and $W_{\text {dry }}$ is weight of the sample after drying.

Determination of percentage ash content $3.5 \mathrm{~g}$ of $\mathrm{BEF}$ was weighed into a pre-weighed crucible and burnt over a Bunsen burner flame until there was no more smoke. The same crucible containing the burnt sample was then placed in an oven with temperature set at $600{ }^{\circ} \mathrm{C}$ and heated until the sample turned gray-white (ash). Then, the crucible was cooled in a desiccator and weighed to a constant weight in order to calculate for the ash content of the sample as Eq. 5:

$\operatorname{Ash}$ content $(\%)=\left(\frac{W_{\text {ash }}}{W_{\text {sample }}}\right) \times 100$

where $W_{\text {ash }}$ is weight of ash and $W_{\text {sample }}$ is weight of the sample.

Determination of percentage oil content Twenty grams of BEF granules was weighed into a filter paper, wrapped and placed inside the inner part of Soxhlet extractor. The apparatus was then fitted to a round bottom flask which contained $200 \mathrm{~mL}$ of hexane solvent and attached to a reflux condenser. The setup was clamped and heated over a water bath until the extracting solution becomes clear. Then, the solvent was distilled off from the distillation set, while the oil was poured into a bottle and allowed to stand for 5 days to allow complete evaporation of the remaining solvent. Weight of the oil was obtained and the percentage oil content determined as expressed in Eq. 6:

Oil content $(\%)=\left(\frac{W_{\text {oil }}}{W_{\text {sample }}}\right) \times 100$

where $W_{\text {oil }}$ is weight of oil and $W_{\text {sample }}$ is weight of the sample.

Determination of percentage protein content Two grams of the BEF was poured into a digestion flask. Eight grams of catalyst $\left(96 \%\right.$ anhydrous $\mathrm{Na}_{2} \mathrm{SO}_{4}, 3.5 \% \mathrm{CuSO}_{4} \cdot 5 \mathrm{H}_{2} \mathrm{O}$,
$0.5 \%$ Selenium oxide) was added. Twenty milliliters of concentrated $\mathrm{H}_{2} \mathrm{SO}_{4}$ was added in an inclined position and stirred occasionally for $2 \mathrm{~h}$. The liquid formed was cooled and washed into the distilling flask with distilled water. Fifty milliliters of boric acid (2\%) solution and screened methyl red indicator were introduced into the flask. The distillation apparatus was properly connected and the delivery tube immersed below the boric acid solution. Fifty percent $\mathrm{NaOH}$ solution was used to increase the alkalinity of the diluted digest. Thereafter, $50 \mathrm{~mL}$ of the distillate was collected and titrated with $0.1 \mathrm{M} \mathrm{H}_{2} \mathrm{SO}_{4}$. A blank solution was also titrated under same condition. Hence, the percentage protein content was calculated as follows:

Percentage Nitrogen $=$ Vol.of $0.1 \mathrm{MH}_{2} \mathrm{SO}_{4} \times 0.28$

Protein $(\%)=\%$ Nitrogen $\times 6.25$

\section{Instrumental characterization of BEF}

The following instrumental analyses: scanning electron microscopy (SEM), Fourier transform infrared (FTIR), differential scanning calorimetry (DSC) and thermo-gravimetric analysis (TGA) were carried out on the sample.

SEM The scanning electron microscopy was performed using scanning electron microscopic unit (Phenom, Pro X model, Eindhoven de Netherlands). The instrument was used to view the morphology of the sample (Chong et al. 2001).

FTIR The analysis was performed using FTIR spectrophotometer (Nicolet, IS 10 model, USA). It was used to determine the functional groups present in sample. The spectrum was measured within the range of $4000-400 \mathrm{~cm}^{-1}$ wave numbers (Leclerc 2000; Chong et al. 2001).

DSC and TGA These analyses were performed using differential scanning calorimetric and thermo-gravimetric analysis units DSC-Q200 V24.10 and TGA-Q50 V20.13 (Kyoto, Japan). The analyses were aimed at characterizing the rate of heat flow, thermal stability/decomposition and the weight loss of the coagulant sample with respect to temperature change (Vyazovkin 2012; Gill et al. 2010).

\section{Effect of process parameters on coagulation- flocculation}

\section{Effect of varying coagulant dosage}

In order to study the effect of coagulant dosage, varying BEC dosages $(0.5,1,2,3,4$ and $5 \mathrm{~g} / \mathrm{L})$ were dosed into six beakers each containing $600 \mathrm{~mL}$ of PWW sample at the initial $\mathrm{pH}$ value of 8 . The coagulation-flocculation processes were carried out as outlined: 
a. The beakers containing the mixtures of effluent and coagulant were placed on magnetic stirrer and subjected to rapid mixing/stirring of $250 \mathrm{rpm}$ for $2 \mathrm{~min}$.

b. Then a slow mixing/stirring of $30 \mathrm{rpm}$ for $20 \mathrm{~min}$. At the end of slow mixing, the effluents were allowed to settle for $40 \mathrm{~min}$.

c. On settling, $20 \mathrm{~mL}$ of the supernatant (upper layer of the settling effluent) was carefully removed at $3 \mathrm{~min}$ and pipetted into $50-\mathrm{mL}$ plastic bottles. It was repeated at varying time ranges of $5,10,15,20,25,30$ and $35 \mathrm{~min}$, respectively.

d. The residual turbidity of each supernatant collected at specified time was measured and recorded.

The residual turbidities recorded in $(\mathrm{d})$ were converted from NTU to $\mathrm{mg} / \mathrm{g}$ and the values used to evaluate the percentage TDSP removal efficiencies following Eq. 9 expression.

\section{Effect of varying effluent $\mathrm{pH}$}

To investigate the effect of $\mathrm{pH}$ on the removal of TDSP, jar test was carried out at varying $\mathrm{pH}(2,4,6,8$ and 10) using optimum dosage obtained in "Effect of varying coagulant dosage" section. The $\mathrm{pH}$ values were adjusted with $0.1 \mathrm{M}$ $\mathrm{NaOH}$ and/or $0.1 \mathrm{M} \mathrm{H}_{2} \mathrm{SO}_{4}$.

The optimum dosage was dosed into five beakers containing $600 \mathrm{~mL}$ PWW. Steps (a)-(d) as outlined in "Effect of varying coagulant dosage" section were repeated sequentially for the optimum $\mathrm{pH}$ determination.

\section{Effect of temperature}

This study was investigated to determine the effect of temperature on the process. Jar test was carried out using the predetermined optimum dosage and $\mathrm{pH}$. At the end of slow mixing, the effluent was allowed to settle with supernatant solution carefully and the residual turbidity measured and recorded. The procedure was repeated for varying temperature values of $25^{\circ} \mathrm{C}, 35^{\circ} \mathrm{C}$ and $45^{\circ} \mathrm{C}$, considering the probable low and high temperature peaks of the surface water for the location where this study was conducted. Furthermore, at about below 25 and above $45{ }^{\circ} \mathrm{C}$, there exist possible onset of flocs clogging and breakage, respectively.

\section{Effect of settling time}

In order to investigate the effect of settling time on the process, jar test was carried out using the predetermined optimum dosage and $\mathrm{pH}$. At the end of slow mixing, the effluent was allowed to settle for 40 min during which supernatant solution was carefully taken at specified time intervals 0-40 min and the residual turbidity measured and recorded.

\section{Analytical method}

The supernatant samples were withdrawn with the aid of syringe at specified time range $(0-30 \mathrm{~min})$ to determine residual turbidity. The TDSP removal efficiency (\%) and the adsorption capacity, $q_{t}(\mathrm{mg} / \mathrm{g})$, were calculated by applying Eqs. 9 and 10:

Removal Eff. $(\%)=\frac{T_{o}-T_{i}}{T_{o}} \times 100$

$q_{t}=\frac{C_{o}-C_{t}}{m} \times V$

where $T_{o}$ and $T_{i}$ are initial turbidity of effluent and effluent turbidity at any time, $t(\mathrm{mg} / \mathrm{g}), q_{t}$ is the adsorption capacity or the quantity of solid particles adsorbed (coagulated) per dose of adsorbent ( $\mathrm{mg} / \mathrm{g}), C_{o}, C_{t}$ and $\mathrm{m}$ is the initial constant effluent concentration, effluent concentration at any time, $\underline{t}(\mathrm{mg} / \mathrm{L})$ and coagulant/adsorbent dose $(\mathrm{g} / \mathrm{L})$, respectively.

Turbidity value is converted to $\mathrm{mg} / \mathrm{L}$ as a product of 2.35 and turbidity.

\section{Results and discussion}

\section{Instrumental/physicochemical characterization results}

SEM The SEM images as could be observed in Fig. 1a-c of different magnifications $(150 \times, 400 \times, 1600 \times)$ show compact structure with dispersed but continuous crack-like openings. The cracks of varying sizes are generally evenly distributed across the sample surface. The cracks and crevices on the closely packed aggregates cumulatively represent larger surface area that would enhance adequate coagulation and adsorption of particles on the coagulant surface. Furthermore, absence of irregular surfaces, randomly formed aggregates and/or loosely bound clusters would probably imply the absence of amorphous carbon. It has been suggested that compact but porous structures are more favorable to coagulate particles (by bridge aggregation) when compared with branched and irregular aggregate structures (Simate et al. 2012).

FTIR Fig. 2 shows the plot of IR transmittance (\%) against wave numbers $\left(\mathrm{cm}^{-1}\right)$ for the FTIR spectrum of BEC. FTIR library was used to analyze the result, and it was compared with known signature of identified materials. The spectrum indicated over six discernible peaks at frequency range of $4000-400 \mathrm{~cm}^{-1}$. The peak ranges of $3307.13 \mathrm{~cm}^{-1}$ and $2924.39 \mathrm{~cm}^{-1}$ depict characteristics of O-H stretching vibrations and indicated the presence of intermolecular hydrogen

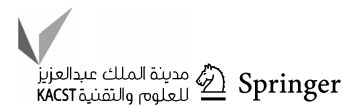



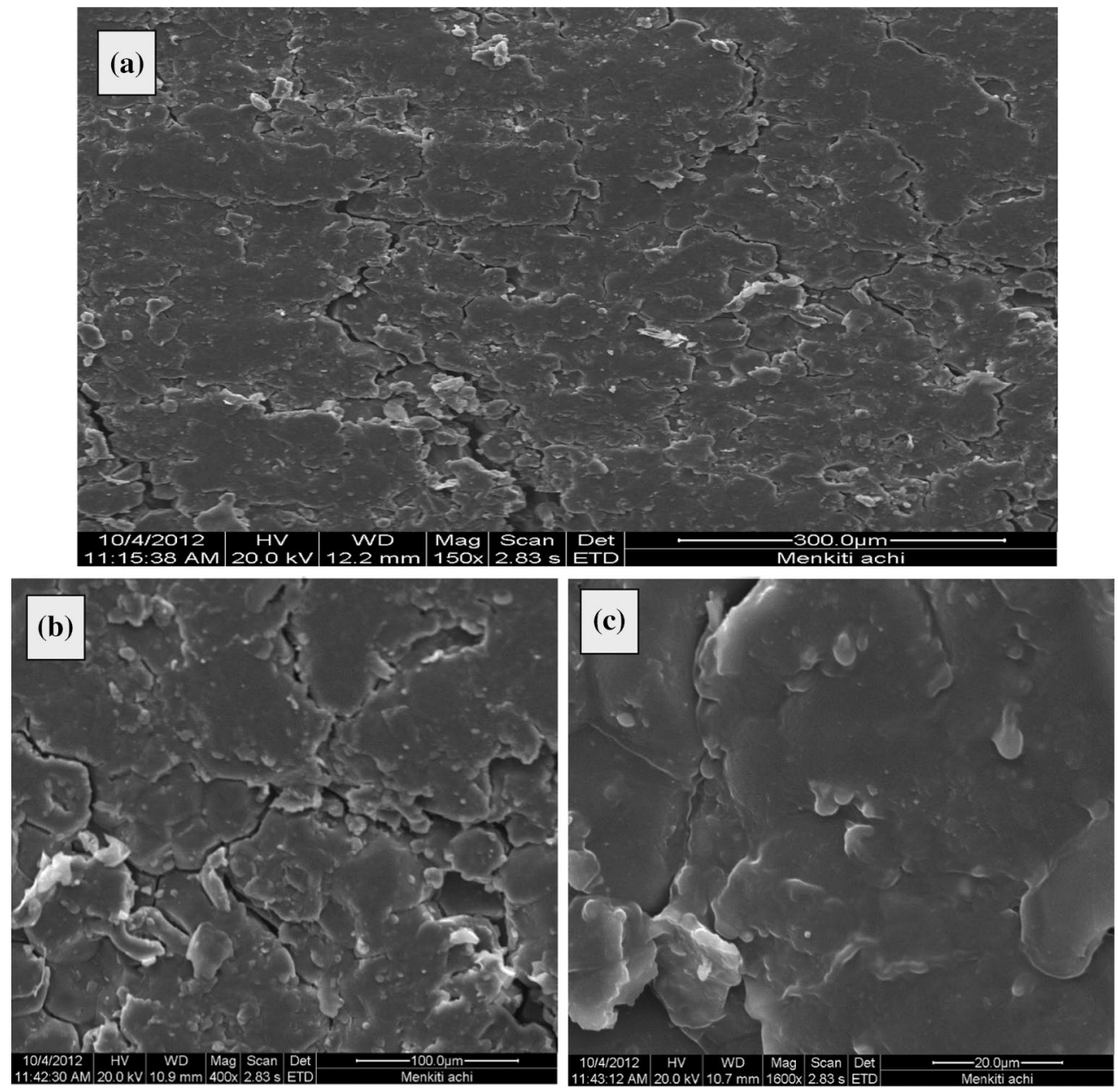

Fig. 1 a-c SEM images of BEC precursor sample at $\times 150, \times 400$ and $\times 1600$ magnifications

Fig. 2 FTIR spectrum chart of Brachystegia eurycoma precursor sample

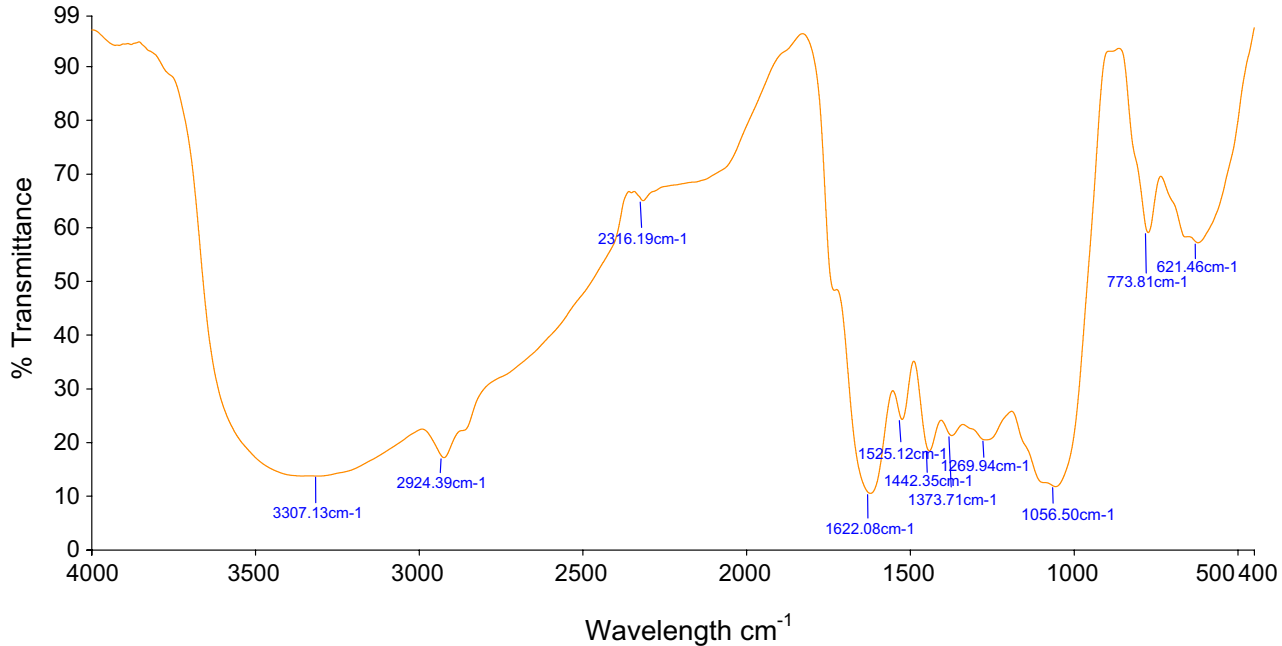

bond groups. The peak range centered at $2924.39 \mathrm{~cm}^{-1}$ shows characteristics of $\mathrm{N}-\mathrm{H}$ stretching which indicated the presence of $1^{\circ}$ and $2^{\circ}$ amines and amides, respectively. On the other hand, the peak at $2316.19 \mathrm{~cm}^{-1}$ was characteristics of $\mathrm{O}=\mathrm{H}$ stretching which depicted the presence carboxylic groups. Furthermore, $1622.08 \mathrm{~cm}^{-1}$ and $1525.12 \mathrm{~cm}^{-1}$ peaks 
show characteristic combinations of $\mathrm{N}=\mathrm{O}$ bending and $\mathrm{C}-\mathrm{N}$ stretching which indicated the presence of aromatic amines and nitro compounds. Similarly, the peaks ranging between 1442.35 and $1056.50 \mathrm{~cm}^{-1}$ were characteristics of $\mathrm{C} \equiv \mathrm{C}$, $\mathrm{C}=\mathrm{C}-\mathrm{H}$ and $\mathrm{H}-\mathrm{C}-\mathrm{H}$ assigned to the vibrating absorption of asymmetric and symmetric stretching in alkanes, alkenes and alkynes, respectively. Generally, the presence of organic molecules, compounds and functional groups recorded for the sample show the ion exchange properties that would improve the dispersion of the samples in liquids such as water. The dissociation of the surface functional groups facilitates the dispersion by creating a negative or positive charge and/or providing hydrophilic sites on a hydrophobic surface (Choudhary and Neogi 2017; Dupuy et al. 1997; Simate et al. 2012; Boehm 1994).

DSC The differential scanning calorimetric (DSC) curve is shown in Fig. 3. According to Menkiti et al. 2014, DSC is a thermal analysis that obtains the function temperature through the difference between the heat flow rate of test sample and a known reference material. The heat flow difference helps to evaluate the quantity of heat intake during phase transition, variation in material composition, crystallinity and oxidation that occurred in BEC sample (Klimiuk et al. 1999; Gill et al. 2010). It could be deduced from Fig. 3 that DSC was used to characterize the phase transition that occurred in BEC sample over the temperature range of 25-297. $5^{\circ} \mathrm{C}$. The figure denotes a sharp thermal transition in the temperature range of $102.5-150{ }^{\circ} \mathrm{C}$ with transition enthalpy of $324.2 \mathrm{~kJ} / \mathrm{kg}$. The resulting transition behavior could be attributed to the de-stringing and coiling of carbon chain leading to spontaneous densification (Menkiti et al.
2014; Ramani et al. 2012). The glass transition temperature was observed between 25 and $31.25^{\circ} \mathrm{C}$ within which the onset, midpoint and offset transition points were observed at $25^{\circ} \mathrm{C}, 27^{\circ} \mathrm{C}$ and $31.25^{\circ} \mathrm{C}$, respectively. The densification of the aggregated mass took place at $175-196{ }^{\circ} \mathrm{C}$ without absorption of thermal energy. The DSC curve shows that the heat flow disks indicated exothermicity.

TGA The TGA analysis is dependent on measurement of mass loss of material as a function of temperature. According to Menkiti et al. 2014, the weight loss could be attributed to chemical reaction (decomposition, combustion) and physitransition (evaporation, desorption, drying) occurring in BEC sample (Vyazovkin 2012). Figure 4 shows the thermal decomposition of the sample and reveals the weight loss of $12.24,16.52,29.89,43.78$ and $58.68 \%$ recorded for temperature values of $117.6,250.28,334.44,361.73$, and $514.12^{\circ} \mathrm{C}$, respectively. The initial weight loss at $100{ }^{\circ} \mathrm{C}$ was found to be $1.804 \mathrm{mg}$ with residue of $16.240 \mathrm{mg}$, which could possibly be as a result of the internal moisture and gaseous loss from the matrix molecules. Furthermore, the subsequent weight losses could be attributed to the decomposition of the labile component and changes due to polymerization and loss of water from hydroxyl groups in the coagulant sample (Debnath and Ghosh 2008). These correspond to the broad exothermic DSC peak between 102.5 and $297.5^{\circ} \mathrm{C}$.

Tables 1 and 2 indicate the basic characteristics of PWW and BEF. The significantly high particle load (NESREA, 2005) comprising TSS (2690 mg/L), TDS(1320 mg/L), TS(4010) and initial turbidity (1706.5NTU) indicated need to subject the PWW to coagulation/flocculation treatment. Furthermore, relatively high BEC yield (90\%) and protein
Fig. 3 DSC chart of Brachystegia eurycoma precursor sample

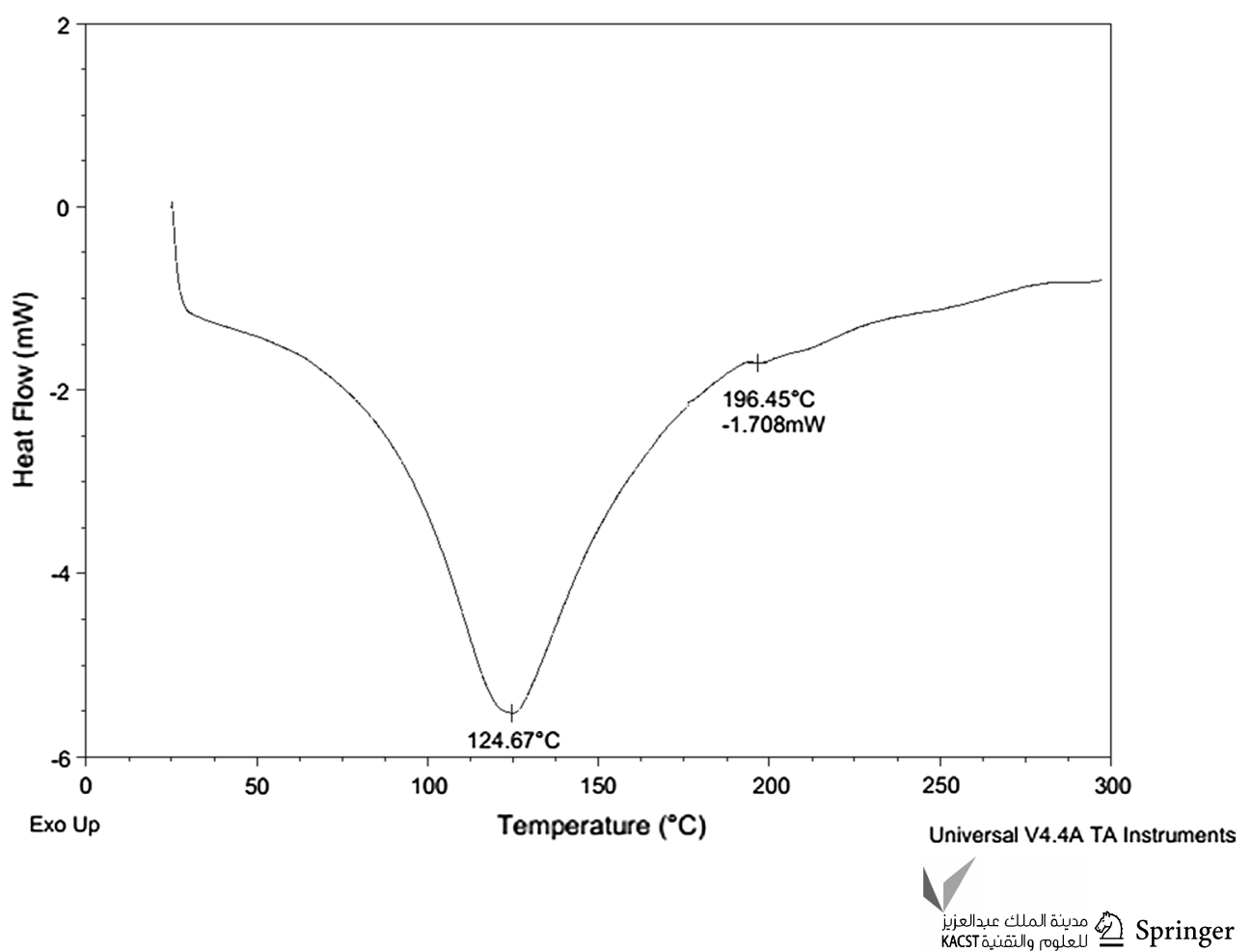


Fig. 4 TGA chart of Brachystegia eurycoma precursor sample

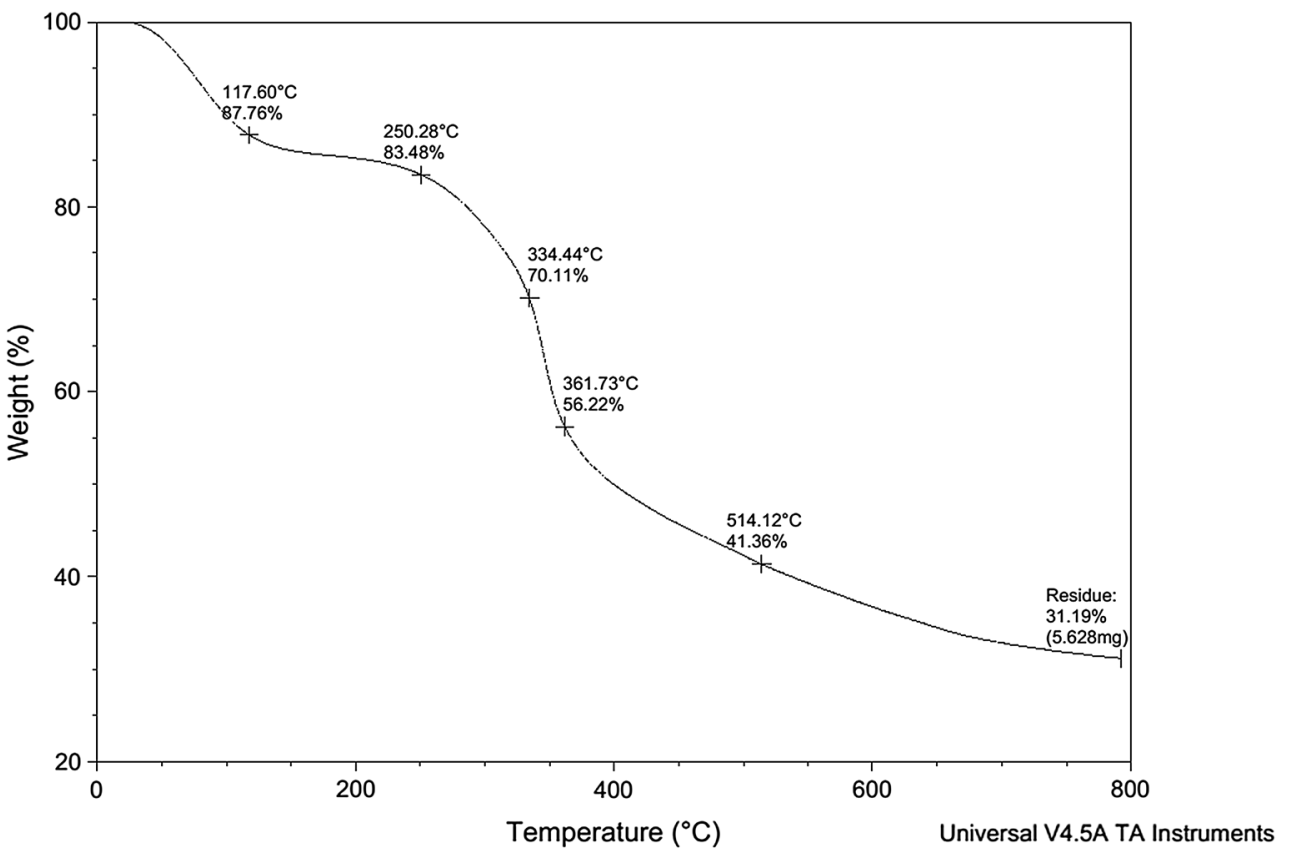

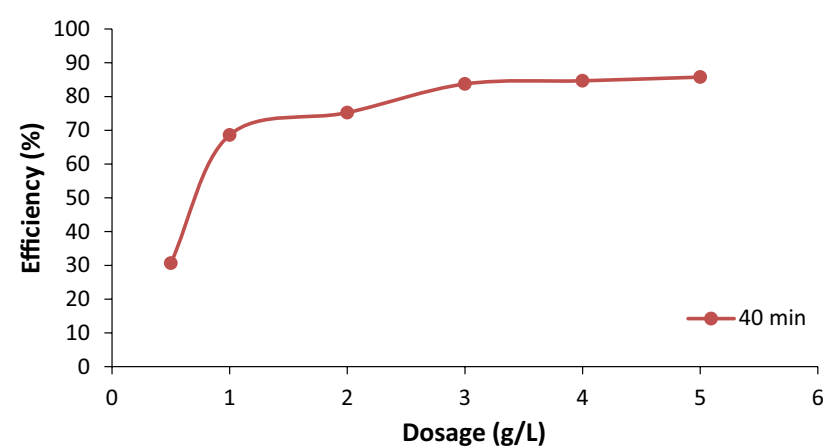

Fig. 5 The plot of coagulant dosage effect at 40 min settling time

content of $21 \%$ indicate the applicability of BEF as precursor for BEC.

\section{Influence of process parameters on TDSP removal efficiency}

\section{Effect of varying coagulant dosage on TSDP removal efficiency}

The plot shown in Fig. 5 represents the effect of varying coagulant dosage (between 0.5 and $5 \mathrm{~g} / \mathrm{L}$ ) on TDSP removal efficiency at the initial $\mathrm{pH}$ of PWW and specified settling time of $40 \mathrm{~min}$. From the plot, a progressive increase in TDSP removal efficiency was observed as the coagulant dosage increased. This could be attributed to the interactions between BEC and PWW molecules, following the availability of positive charges provided by the coagulant particles, which ultimately enhanced destabilization/neutralization of the negatively charged TDSP particles in PWW (Wei et al. 2009; Abdulsahib et al. 2015). The maximum efficiency was attained at coagulant dosage of $5 \mathrm{~g} / \mathrm{L}$. However, BEC was believed to possess attributes of high ionic strength (anionic coagulant) which favors flocculation of colloidal particles on a low conductivity effluent (Roussy et al. 2004; Assaad et al. 2007). Hence, BEC was understood to behave like a pre-hydrolyzed coagulant under the conditions of the experiment.

\section{Effect of $\mathrm{pH}$ on TSDP removal efficiency}

According to Thirugnanasambandham and Sivakumar (2014), pH plays vital role in coagulation treatment process. Figure 6 shows the plot of percentage TDSP removal efficiency at varying $\mathrm{pH}$ ranges. The following deductions and interpretations were drawn from the graphical trend. Optimum $\mathrm{pH}$ was reached at $\mathrm{pH} 8$. The region of increase in removal efficiency could be attributed to progressive protonation as positive species progressively conjugated with available negative species toward equilibrium. The decreasing region was as a result of net negative species-induced charge reversal, which entails re-stabilization and coagulation recession. The maximum TDSP removal efficiency of $85.75 \%$ was attained at optimum $\mathrm{pH}$ of 8 , which was the initial PWW pH. This could be as a result of polar and hydrophilic functional groups in the effluent that resulted in easy aggregation at this region of $\mathrm{pH}$ (Madukasi et al. 2009). Favorable aggregation at $\mathrm{pH}$ above 8 is in line with the behavior of anion predominated coagulant-flocculant (Wei et al. 2009; Roussy et al. 2004; Al-Rasheed 2005). According to Debnath and Ghosh (2008), the decrease observed 


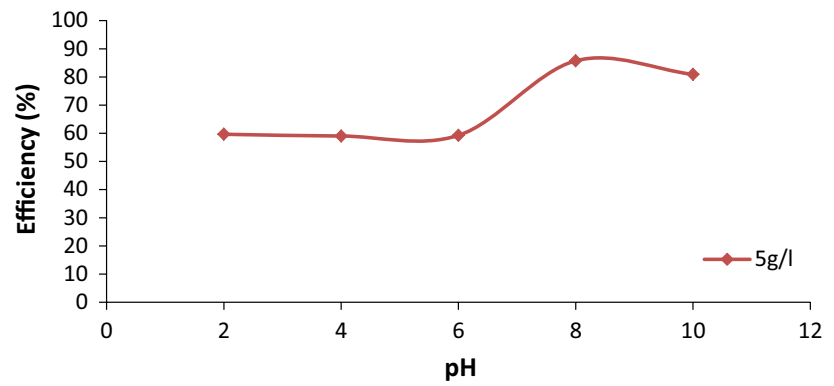

Fig. 6 The plot of $\mathrm{pH}$ effect at $5 \mathrm{~g} / \mathrm{L}$ coagulant dosage and varying $\mathrm{pH}$ values

after the maximum $\mathrm{pH} 8$ was attained presumably due to the decrease in the anion exchange property of BEC sample, change in the chemical form of PWW with increasing $\mathrm{pH}$ and restructuration of the coagulant particles. However, the most likely coagulation mechanism exhibited in this study of $\mathrm{pH}$ effect seems to be charge neutralization. Similar result was reported in the "removal of ecotoxicological matters from tannery wastewater using electrocoagulation process" (Thirugnanasambandham and Sivakumar 2014).

\section{Effect of temperature on TSDP removal efficiency}

The plot of Fig. 7 represents the removal efficiency against time at varying temperatures. The graph indicates that the removal efficiency achieved at the incipient stage was $>85 \%$ for the temperatures of $35{ }^{\circ} \mathrm{C}$ and $45^{\circ} \mathrm{C}$. Maximum TDSP removal efficiency was attained at $25 \mathrm{~min}$ and $35^{\circ} \mathrm{C}$. The removal efficiency was maintained for all temperatures at $25 \mathrm{~min}$. However, the suppressed efficiency obtained at above $35{ }^{\circ} \mathrm{C}$ could be as a result of floc breakage due to excess heat intake (Wei et al. 2009). Also, the progressive increase attained between 0 and $25 \mathrm{~min}$ for TDSP removal efficiencies could be attributed to significant number of active sites and increasing kinetic energy for the aggregating particles as temperature increased beyond $25-35^{\circ} \mathrm{C}$. It could be noted that increasing temperature provided increasing

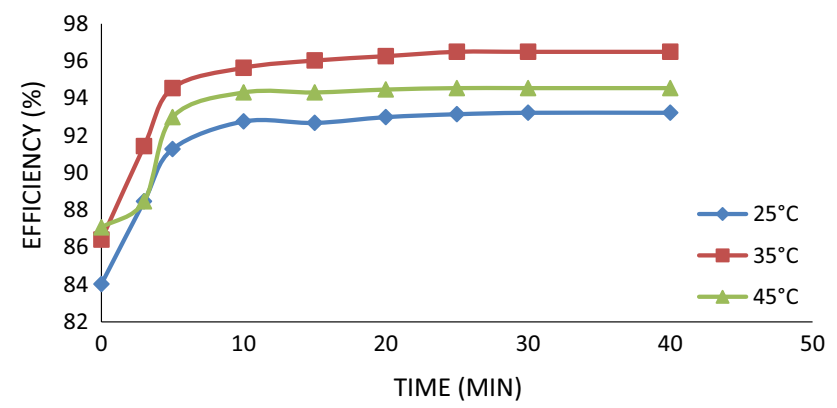

Fig. 7 The plot of temperature effect at $5 \mathrm{~g} / \mathrm{L}$ dosage, $\mathrm{pH} 8$ and varying temperatures solubility and dispersion, which aid viable floc formation and subsequent sedimentation of flocs. According to Simate et al. (2012), relatively lower solubility factors contributed to the lower removal efficiency observed at $25^{\circ} \mathrm{C}$.

\section{Effect of settling time on TSDP removal efficiency}

The results presented in Fig. 8 show the plot of TDSP removal efficiency against time. The effect of settling time was carried out following the suitable temperature of $35^{\circ} \mathrm{C}$ as obtained in "Effect of temperature on TSDP removal efficiency" section. It was deduced from the plot that TDSP removal efficiency increased with increase in flocculation time until the optimum coagulation time of $25 \mathrm{~min}$, which complies with the time where maximum efficiency of $96.5 \%$ was also attained in "Effect of temperature on TSDP removal efficiency" section. The increased removal efficiency observed at flocculation time below equilibrium could be attributed to the sustained dispersion and destabilization of charged species. At and after equilibrium onset, the steady removal efficiency $(96.50 \%)$ maintained after 25 min resulted from constant destabilization and aggregation rates, in addition to steadied reduction in amount of soluble coagulant that resulted in steadied weakened interaction of opposing charge species. The progressive increase in the removal efficiencies achieved between 0 and $25 \mathrm{~min}$ shows that coagulation rate was high at the incipient stage of coagulation-flocculation process because of the large number of active coagulants sites available for destabilization activities (Abdulsahib et al. 2015; Menkiti et al. 2014; Thirugnanasambandham and Sivakumar 2014; Tzoupanos and Zouboulis 2008).

\section{Influence of contact time and coagulant dosage on adsorptive capacity}

Figure 9 shows the plot of variation of adsorption capacity, $q_{t}(\mathrm{mg} / \mathrm{g})$ with contact time and coagulant dosage. It could be seen from the plot that $q_{t}$ increased with decreasing

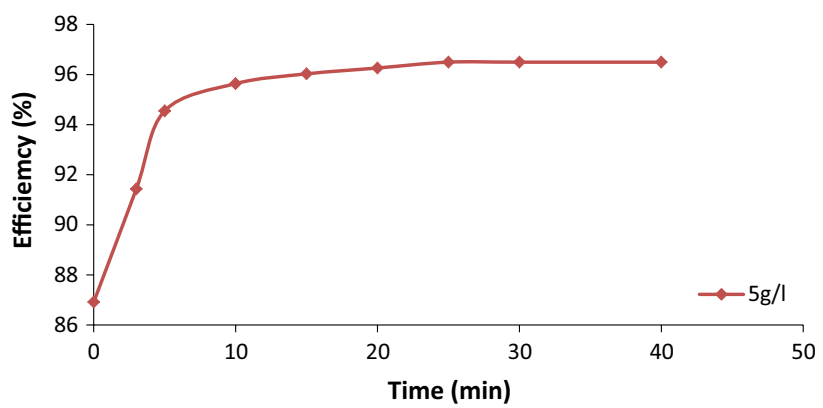

Fig. 8 The plot of settling time at $5 \mathrm{~g} / \mathrm{L}$ coagulant dosage, $\mathrm{pH} 8$ and $35^{\circ} \mathrm{C}$ 
coagulant dosage and increasing contact time. $q_{t}$ attained equilibrium at $20 \mathrm{~min}$. The increase in, $q_{t}$, as the coagulant dosage decreased could be due to the progressive saturation of coagulants active positive charged sites by PWW negative charges. Decreasing coagulant dosage entails decreasing available total active surface area of the coagulant, resulting in increasing mass concentration of destabilized particles per unit mass of the decreasing coagulant dose (Menkiti et al. 2014). The optimum adsorption capacity, $q_{t}$, was obtained at $0.5 \mathrm{~g} / \mathrm{L}$, while the lowest $q_{t}$ was obtained at $5 \mathrm{~g} / \mathrm{L}$. From the plot, it could be observed that the adsorption capacity, $q_{t}$, at $0.5 \mathrm{~g} / \mathrm{L}$ had a minimum and maximum values of 1273.7 and $1417.05 \mathrm{mg} / \mathrm{g}$ at contact times of 0 and $40 \mathrm{~min}$, respectively, while the $q_{t}$ at $5 \mathrm{~g} / \mathrm{L}$ had a minimum and maximum values of 115.39 and $120.79 \mathrm{mg} / \mathrm{g}$ at contact times of 0 and $40 \mathrm{~min}$, respectively.

\section{Kinetic analysis}

The experimental data were analyzed using three traditional kinetics (reversible first order, pseudo-second order and Elovich models) and intra-particle diffusion models. The latter would determine the rate-controlling step (Debnath and Ghosh 2008; Vazquez et al. 2002). The governing Eqs. 11-13 for both linear and nonlinear kinetic plots are presented in Table 3. Figure 10 shows the nonlinear kinetic plots at the best operating conditions (coagulant dosage and $\mathrm{pH}$ ), while the kinetic parameters for both linear and nonlinear were evaluated from the slopes and intercepts of the kinetic plots (linear plots not shown) and presented in Table 4.

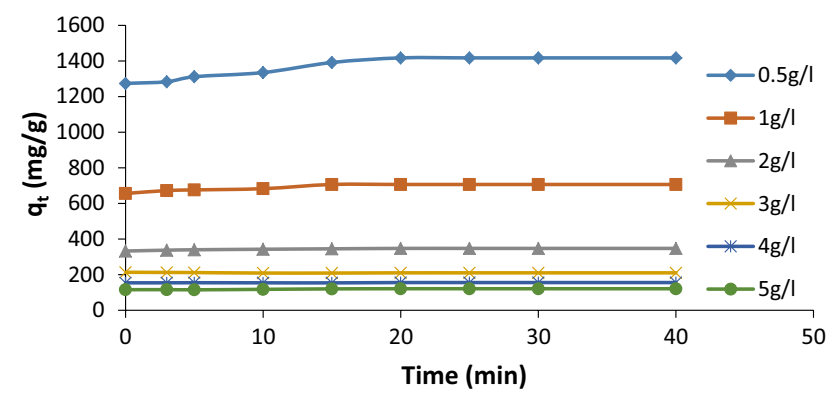

Fig. 9 The plot of adsorptive capacity, $q_{\mathrm{t}}$, against contact time, $t$
Figure 10a-c shows the plot of experimental data of $\mathrm{q}_{\mathrm{t}}$ against time as a measure for accessing other models. Following the results, Pseudo-second-order model was found, not only to follow the same trend as the experimental but to have the most similar and close data to the experimental. When compared to the other kinetic models evaluated, it was observed explicitly that the model provides best fit to the kinetic data with highest $R^{2}$ values above 0.99 and least value of SSE $(<2.495 \%)$. Also, the model relative error estimated between the linear and nonlinear indicated mostly insignificant percentage deviation of the linear constants from nonlinear.

\section{Rate-limiting step}

Adsorption kinetics could be controlled by several independent factors (bulk diffusion, film diffusion, chemical reaction, intra-particle diffusion, temperature, $\mathrm{pH}$, etc.) that could act individually or interactively (Menkiti et al. 2014). According to Debnath and Ghosh (2008), Weber-Morris explained that if the rate-limiting step is the intra-particle diffusion, then the amount of BEC adsorbed at any time, $t$, should be directly proportional to the square root of contact time, $t$. This can be expressed mathematically as shown in Eq. 14 .

$q_{t}=K_{\mathrm{id}} t^{0.5}$

Linearizing Eq. 14 results to Eq. 15:

$\log q_{t}=\log K_{\text {id }}+0.5 \log t$

where $q_{t}$ is the amount of coagulant adsorbed at time, $t(\mathrm{~min})$ and $K_{\mathrm{id}}$ is the intra-particle rate constant $\left(\mathrm{mg} / \mathrm{g} \mathrm{min}^{-0.5}\right)$.

The plot of $\log q_{t}$ against $0.5 \log t$ gives a straight line with positive intercept for intra-particle diffusion-controlled adsorption process. If the calculated intra-particle diffusion coefficient, $D_{\mathrm{P}}$, value falls in the range of $10^{-11}$ to $10^{-13}$ $\mathrm{cm}^{2} / \mathrm{s}$, then the rate-determining step will be intra-particle diffusion. Also, if the calculated film diffusion, $D_{\mathrm{F}}$, value is found within the range $10^{-6}$ to $10^{-8} \mathrm{~cm}^{2} / \mathrm{s}$, then the ratelimiting step will be controlled by film (boundary-layer) diffusion (Debnath and Ghosh 2008, Menkiti, et al. 2014).

In this study, Fig. 11 shows the graphical representation of $\log q_{t}$ against $0.5 \log t$. The plot is found to be linear with $R^{2}>0.9$. The calculated diffusion coefficient, $D_{\mathrm{P}}$, values as presented in Table 4 clearly shows that the values lie between $10^{-11}$ and $10^{-15}$. Thus, intra-particle diffusion
Table 3 Linear and nonlinear kinetic models

\begin{tabular}{|c|c|c|c|}
\hline Model & Linear & Nonlinear & Equation nos. \\
\hline Reversible first order: & $\ln \left(1-U_{t}\right)=-K_{1} t$ & & (11) \\
\hline Pseudo-second order: & $t / q_{t}=1 /\left(K_{2}^{2} q_{\mathrm{e}}^{2}\right)+1 / q_{\mathrm{e}}$ & $q_{t}=\frac{t}{\frac{1}{\left(k q_{\mathrm{e}}^{2}\right)}+\frac{t}{q_{\mathrm{e}}}}$ & (12) \\
\hline Elovich: & $q_{t}=(1 / \beta) \ln (\alpha \beta)+(1 / \beta) \ln t$ & $q_{t}=\frac{1}{\beta} \ln (1+\alpha \beta t)$ & (13) \\
\hline
\end{tabular}



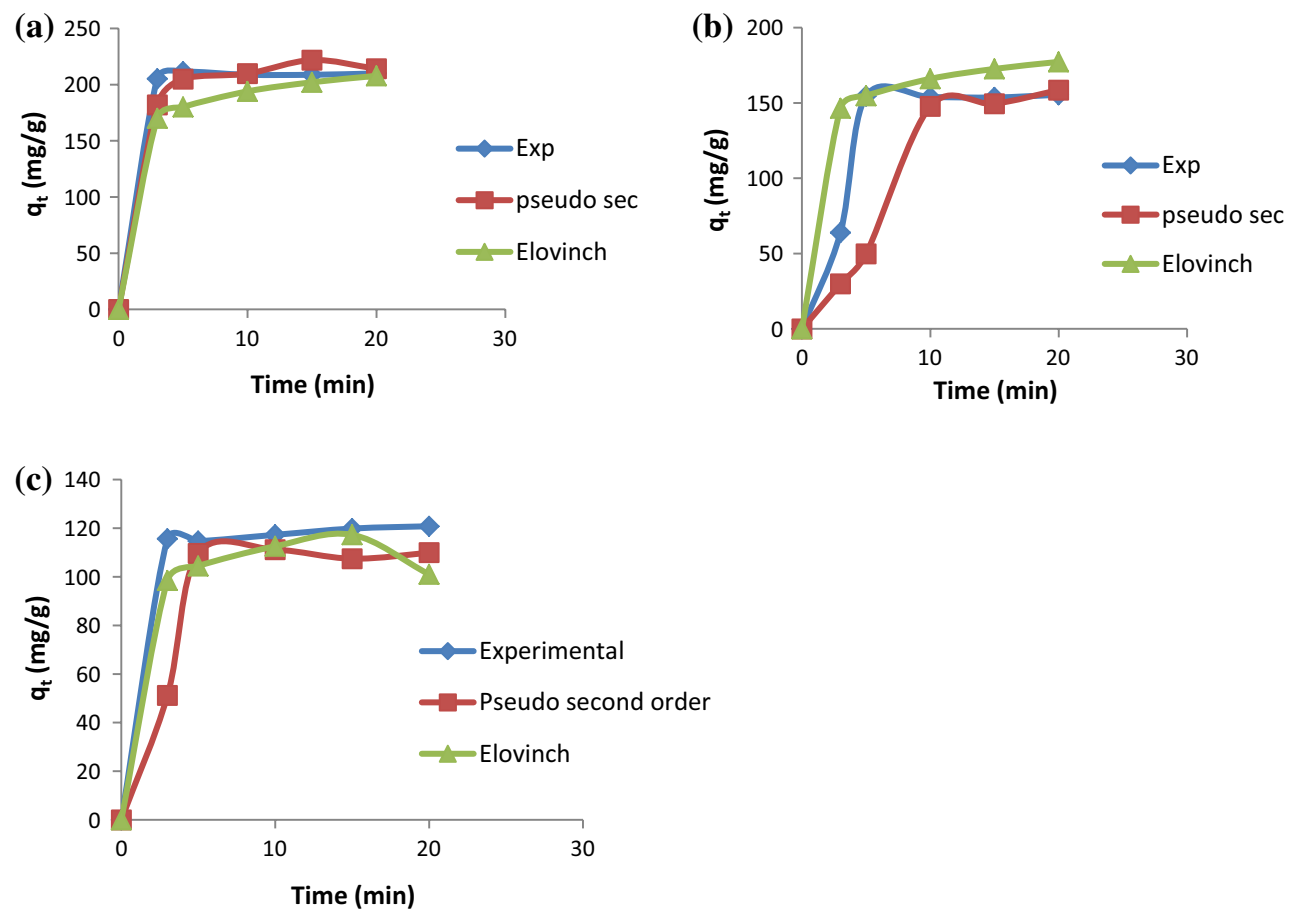

Fig. 10 Nonlinear kinetic plots at selected coagulant dosages a 1 g/L, b 3 g/L and c 5 g/L

Table 4 Calculated kinetic parameters at varying coagulant dosage

\begin{tabular}{|c|c|c|c|c|c|c|}
\hline Kinetic model & $0.5(\mathrm{~g} / \mathrm{L})$ & $1.0(\mathrm{~g} / \mathrm{L})$ & $2.0(\mathrm{~g} / \mathrm{L})$ & $3.0(\mathrm{~g} / \mathrm{L})$ & $4.0(\mathrm{~g} / \mathrm{L})$ & $5.0(\mathrm{~g} / \mathrm{L})$ \\
\hline \multicolumn{7}{|c|}{ Reversible first order } \\
\hline$K_{1}\left(\min ^{-1}\right)$ & 0.1364 & 0.1225 & 0.1458 & 0.1225 & 0.0911 & 0.0755 \\
\hline$R^{2}$ & 0.991 & 0.988 & 0.998 & 0.988 & 0.998 & 0.999 \\
\hline SSE $(\%)$ & 4.341 & 4.094 & 3.992 & 3.016 & 4.171 & 3.003 \\
\hline \multicolumn{7}{|c|}{ Pseudo-second order: linear parameters } \\
\hline$K_{2}(\mathrm{~g} / \mathrm{mg} \min )$ & 0.0011 & 0.0017 & 0.0018 & 0.0044 & 0.00281 & 0.0267 \\
\hline$q_{\mathrm{e}}(\mathrm{mg} / \mathrm{g})$ & 433.33 & 482.05 & 555.56 & 616.67 & 672.58 & 850.72 \\
\hline$R^{2}$ & 0.997 & 0.995 & 0.997 & 0.999 & 0.999 & 0.999 \\
\hline $\operatorname{SSE}(\%)$ & 2.495 & 2.437 & 2.529 & 2.102 & 1.801 & 1.335 \\
\hline \multicolumn{7}{|c|}{ Nonlinear parameters } \\
\hline$K_{2}(\mathrm{~g} / \mathrm{mg} \min )$ & 0.0014 & 0.00215 & 0.0021 & 0.0272 & 0.02438 & 0.02716 \\
\hline$R^{2}$ & 0.917 & 0.955 & 0.967 & 0.969 & 0.997 & 0.998 \\
\hline $\operatorname{MRE}(\%)$ & 21.42857 & 9.210037 & 14.28571 & 83.82353 & 88.47416 & 1.693667 \\
\hline \multicolumn{7}{|c|}{ Elovich: linear parameters } \\
\hline$\alpha(\mathrm{mg} / \mathrm{g} \min )$ & 0.0128 & 0.0143 & 0.0189 & 0.0391 & 0.0628 & 0.0848 \\
\hline$\beta(\mathrm{g} / \mathrm{mg})$ & $17,862.01$ & $32,983.42$ & $14,932.84$ & $33,213.02$ & $44,847.00$ & $17,844.58$ \\
\hline$R^{2}$ & 0.941 & 0.947 & 0.944 & 0.977 & 0.960 & 0.987 \\
\hline $\operatorname{SSE}(\%)$ & 7.112 & 6.903 & 5.027 & 5.405 & 4.729 & 4.415 \\
\hline \multicolumn{7}{|c|}{ Nonlinear parameters } \\
\hline$\alpha(\mathrm{mg} / \mathrm{g} \min )$ & 0.0132 & 0.015 & 0.049 & 0.050 & 0.062 & 0.086 \\
\hline$\beta(\mathrm{g} / \mathrm{mg})$ & 17,921 & 34,326 & 33,401 & $33,200.06$ & 44,845 & 17,847 \\
\hline$R^{2}$ & - & - & - & - & - & - \\
\hline $\operatorname{MRE}(\%)$ & 3.030303 & 5.298 & 61.50 & 21.95 & 5.706 & 0.935 \\
\hline$K_{\text {id }}\left(\mathrm{mg} / \mathrm{g} \min ^{1 / 2}\right)$ & 435.07 & 438.60 & 271.71 & 241.99 & 200. & \\
\hline$D_{\mathrm{p}}\left(\mathrm{cm}^{2} / \mathrm{s}\right)$ & $3.19 \mathrm{E}-11$ & $1.31 \mathrm{E}-11$ & $2.60 \mathrm{E}-12$ & $2.54 \mathrm{E}-12$ & $1.3 \mathrm{E}-14$ & $1.30 \mathrm{E}-15$ \\
\hline$R^{2}$ & 0.948 & 0.964 & 0.978 & 0.969 & 0.966 & 0.988 \\
\hline
\end{tabular}




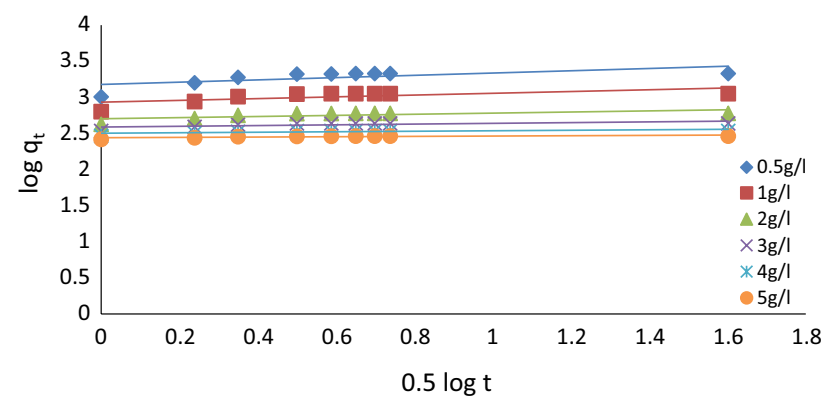

Fig. 11 Weber-Morris (intra-particle diffusion) plot

is considered the rate-controlling/rate-limiting step for the process which is in agreement with the previous report presented by Debnath and Ghosh (2008).

\section{Isothermic analysis}

The equilibrium study was carried out using three isotherm models (Langmuir, Freundlich and Temkin) in order to evaluate the nature of adsorption and the maximal adsorption capacity. The isotherm parameters were estimated using both linear and nonlinear forms of the models expressed as Eqs. 16, 17 and 18 in Table 5 (Foo and Hameed 2010; Goldberg 2005; Vazquez et al. 2002):

Where $q_{\mathrm{e}}$-amount of coagulant uptake per unit mass of BEC at equilibrium $(\mathrm{mg} / \mathrm{g}) ; q_{\mathrm{m}}$-Langmuir constant related to monolayer coagulation capacity $(\mathrm{mg} / \mathrm{g}) ; K_{\mathrm{F}}, K_{\mathrm{L}}$, $K_{\mathrm{T}}$-isotherm constants for Freundlich, Langmuir and
Temkin $(\mathrm{mg} / \mathrm{g}, \mathrm{L} / \mathrm{mg}) ; C_{\mathrm{e}}$-equilibrium BEC concentration in solution $(\mathrm{mg} / \mathrm{L}) ; b_{\mathrm{T}}$-constant in Temkin isotherm (KJ/mol); $n$-Freundlich constant (dimension less); $T$ absolute temperature $(\mathrm{K})$.

Figure $12 \mathrm{a}$ and $\mathrm{b}$ shows the nonlinear isotherm representation of Freundlich, Langmuir and Temkin isotherm models compared with the experimentally generated $q_{\mathrm{e}}$ at $25^{\circ} \mathrm{C}$ and $45^{\circ} \mathrm{C}\left(35^{\circ} \mathrm{C}\right.$ was not shown $)$. From the plots, it could be observed that Langmuir plot is generally the most correlated to experimental data, followed by Freundlich isotherm, as depicted in Table 6. The linear and nonlinear models parameters [obtained from slopes and intercepts of plots (figures not shown) for the linear isotherm] are shown for the studied temperatures of $25{ }^{\circ} \mathrm{C}, 35^{\circ} \mathrm{C}$ and $45^{\circ} \mathrm{C}$, along with statistical error analyses (correlation coefficient, $R^{2}$, Chi-square, $\chi^{2}$, sum of square error and model relative error). The $R^{2}, \chi^{2}$ and SSE were used to check for the level of accuracy and goodness of fit for the models. The higher the values of $R^{2}$ and the lower the $\chi^{2}$ and SSE values, the better the model. From the parameters in Table 6, Langmuir isotherm among the three models predominantly describes the process under the experimental conditions. Also, it could be observed that the majority of three isotherm model constants (Table 6), for the linear and nonlinear, showed no definite trend with temperature variation. The only exception is Temkin isotherm, in which $K_{\mathrm{T}}$ increased with increase in temperature, probably because temperature has direct relationship with $q_{\mathrm{e}}$ in Temkin model.
Table 5 Linear and nonlinear isotherm model equations used for the analyses of coagulativeadsorptive data

Fig. 12 Nonlinear isotherm plots at selected temperatures of: $\mathbf{a} 25^{\circ} \mathrm{C}$ and $\mathbf{b} 45^{\circ} \mathrm{C}$

\begin{tabular}{lllll}
\hline Model & Nonlinear & Linear & Plot made & Equation nos. \\
\hline Langmuir & $q_{\mathrm{e}}=\frac{K_{\mathrm{m}} K_{1} C_{\mathrm{e}}}{1+K_{1} C_{\mathrm{e}}}$ & $\frac{C_{\mathrm{e}}}{q_{\mathrm{e}}}=\frac{1}{K Q_{a}^{0}}+\frac{C_{\mathrm{e}}}{Q_{a}^{0}}$ & $C_{\mathrm{e}} / q_{\mathrm{e}}$ vs. $C_{\mathrm{e}}$ & $(16)$ \\
Freundlich & $q_{\mathrm{e}}=K_{\mathrm{f}} C_{\mathrm{e}}^{1 / 2}$ & $\log q_{\mathrm{e}}=\log K_{\mathrm{f}}+\frac{1}{n}$ & $\log q_{\mathrm{e}}$ vs. $\log C_{\mathrm{e}}$ & $(17)$ \\
Temkin & $q_{\mathrm{e}}=\frac{R T}{b_{\mathrm{T}}}\left(\ln K_{\mathrm{T}} C_{\mathrm{e}}\right)$. & $q_{\mathrm{e}}=\frac{R T}{b_{\mathrm{T}}} \ln A_{\mathrm{r}}+\left(\frac{R T}{b}\right) \ln C_{\mathrm{e}}$ & $q_{\mathrm{e}}$ vs $\ln C_{\mathrm{e}}$ & \\
\hline
\end{tabular}

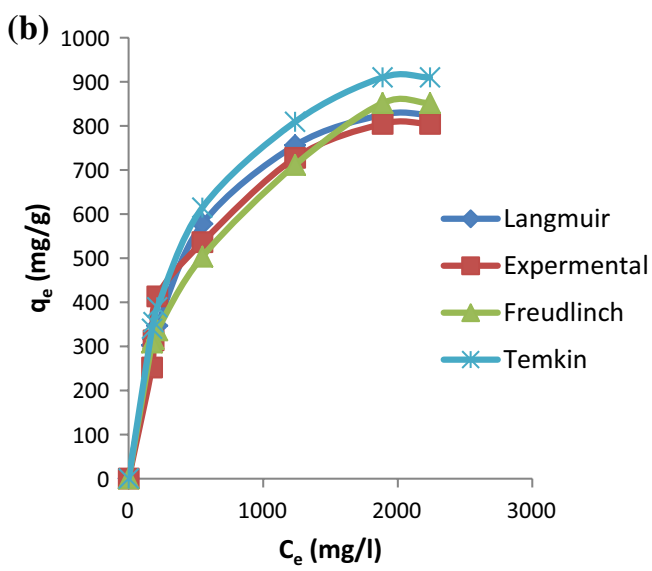


Table 6 Calculated isotherm parameters at varying temperatures

\begin{tabular}{|c|c|c|c|}
\hline Isotherm model & $25^{\circ} \mathrm{C}$ & $35^{\circ} \mathrm{C}$ & $45^{\circ} \mathrm{C}$ \\
\hline \multicolumn{4}{|c|}{ Freundlich: linear parameters } \\
\hline$K_{\mathrm{F}}(\mathrm{L} / \mathrm{g})$ & 10.691 & 14.588 & 46.453 \\
\hline$N$ & 1.706 & 1.739 & 2.770 \\
\hline$R^{2}$ & 0.8640 & 0.9295 & 0.8951 \\
\hline$\chi^{2}$ & 2.6657 & 2.9496 & 2.9550 \\
\hline SSE $(\%)$ & 3.4657 & 3.7561 & 3.8689 \\
\hline \multicolumn{4}{|c|}{ Nonlinear parameters } \\
\hline$K_{\mathrm{F}}(\mathrm{L} / \mathrm{g})$ & 38.8 & 9.53 & 48.01 \\
\hline$N$ & 2.11 & 1.57 & 2.10 \\
\hline$R^{2}$ & 0.90 & 0.93 & 0.99 \\
\hline $\operatorname{MRE}(\%)$ & 72.80 & 23.00 & 3.24 \\
\hline SSE & 150.06 & 70.11 & 40.40 \\
\hline$\chi^{2}$ & 24.30 & 19.10 & 3.89 \\
\hline \multicolumn{4}{|c|}{ Langmuir: linear parameters } \\
\hline$K_{\mathrm{L}}(\mathrm{L} / \mathrm{g})$ & 0.00152 & 0.00204 & 0.00364 \\
\hline$Q_{\mathrm{m}}(\mathrm{mg} / \mathrm{g})$ & 1000 & 1000 & 1000 \\
\hline$R_{\mathrm{L}}$ & 0.2242 & 0.1024 & 0.1078 \\
\hline$R^{2}$ & 0.918 & 0.973 & 0.994 \\
\hline$\chi^{2}$ & 1.8171 & 1.5790 & 0.8164 \\
\hline SSE $(\%)$ & 3.6188 & 2.1084 & 0.9573 \\
\hline \multicolumn{4}{|c|}{ Nonlinear parameters } \\
\hline$K_{\mathrm{L}}(\mathrm{L} / \mathrm{g})$ & 0.00449 & 0.002413 & 0.004788 \\
\hline$Q_{\mathrm{m}}(\mathrm{mg} / \mathrm{g})$ & 1532.50 & 1100 & 1375 \\
\hline$R_{\mathrm{L}}$ & 0.0131 & 0.0741 & 0.0741 \\
\hline$R^{2}$ & 0.989 & 0.931 & 0.995 \\
\hline$\chi^{2}$ & 0.207 & 36.75 & 66.30 \\
\hline $\operatorname{MRE}(\%)$ & 66.10 & 15.60 & 24.20 \\
\hline $\operatorname{SSE}(\%)$ & 6.84 & 62.11 & 73.11 \\
\hline \multicolumn{4}{|c|}{ Temkin: linear parameters } \\
\hline$K_{\mathrm{T}}(\mathrm{L} / \mathrm{g})$ & 0.0125 & 0.0247 & 0.0515 \\
\hline$B(\mathrm{~J} / \mathrm{mg})$ & 17.1934 & 10.3129 & 9.9783 \\
\hline$R^{2}$ & 0.918 & 0.922 & 0.974 \\
\hline$\chi^{2}$ & 5.5322 & 6.7178 & 5.7620 \\
\hline SSE $(\%)$ & 3.1852 & 3.4583 & 3.3550 \\
\hline \multicolumn{4}{|c|}{ Nonlinear parameters } \\
\hline$K_{\mathrm{T}}(\mathrm{L} / \mathrm{g})$ & 0.011323 & 0.0126 & 0.0167 \\
\hline$B(\mathrm{~J} / \mathrm{mg})$ & 5.65 & 5.683 & 6.055 \\
\hline$R^{2}$ & 0.997 & 0.99 & 0.99 \\
\hline$\chi^{2}$ & 7.823 & 3.062 & 2.283 \\
\hline MRE (\%) & 9.00 & 48.00 & 67.57 \\
\hline $\operatorname{SSE}(\%)$ & 56.889 & 24.595 & 26.204 \\
\hline
\end{tabular}

\section{Confirmation of favorability of the adsorption process}

The favorability of the adsorption process was further confirmed using the relationship expressed in Eq. 19 to calculate the dimensionless separation factor $\mathrm{R}_{\mathrm{L}}$ (Menkiti et al. 2014; Debnath and Ghosh 2008).
Table 7 Thermodynamic parameters at varying temperatures

\begin{tabular}{lccc}
\hline Parameter & $25^{\circ} \mathrm{C}(298 \mathrm{~K})$ & $35^{\circ} \mathrm{C}(308 \mathrm{~K})$ & $45^{\circ} \mathrm{C}(318 \mathrm{~K})$ \\
\hline$\Delta G^{\circ}(\mathrm{kJ} / \mathrm{mol})$ & -26.4236 & -28.0067 & -31.6446 \\
$\Delta H^{\circ}(\mathrm{kJ} / \mathrm{mol})$ & & 34.8565 & \\
$\Delta S^{\circ}(\mathrm{kJ} / \mathrm{mol})$ & & 0.2058 & \\
$E_{\mathrm{a}}(\mathrm{kJ} / \mathrm{mol}-\mathrm{s})$ & 36.7885 & \\
\hline
\end{tabular}

$R_{\mathrm{L}}=\left[1+\left(K_{\mathrm{L}} C_{o}\right)\right]^{-1}$

where $K_{\mathrm{L}}$ is Langmuir constant $(\mathrm{L} / \mathrm{mg})$ and $C_{o}$ is the initial PWW concentration $(\mathrm{mg} / \mathrm{L})$.

According to Debnath and Ghosh (2008), the dimensionless separation factor, $R_{\mathrm{L}}$, was a tool used to indicate the shape of the isotherm as follows: the isotherm is (1) unfavorable when $R_{\mathrm{L}}>1$, (2) linear when $R_{\mathrm{L}}=1$, (3) favorable when $R_{\mathrm{L}}<1$ and (4) irreversible when $R_{\mathrm{L}}=0$. Based on the parameters presented in Table $6, R_{\mathrm{L}}$ values clearly exceeded zero (0) and fall below unity (1), i.e., $\left(0>R_{\mathrm{L}}<1\right)$ both for linear and nonlinear Langmuir isotherms. Hence, $R_{\mathrm{L}}$ indicates process favorability for Langmuir predominated process. Also, since n-values for Freundlich model lie between 1.0 and 3.0, the process would be considered favorable, since n-values of 1-3 are within Freundlich threshold range of $1-10$.

\section{Thermodynamics}

Thermodynamic study was performed to ascertain the feasibility and spontaneity of the process. Equation 20 was used to evaluate the Gibb's free energy change of the process at temperature values of $25^{\circ} \mathrm{C}, 35^{\circ} \mathrm{C}$ and $45^{\circ} \mathrm{C}$.

$\Delta G=-R T \ln K_{\mathrm{L}}$

A relation of Gibb's free energy change $\left(\Delta G^{\circ}\right)$ to enthalpy change $\left(\Delta H^{\circ}\right)$ and entropy change $\left(\Delta S^{\circ}\right)$ at constant temperature is shown in Eq. 21:

$\ln K_{\mathrm{L}}=\left(\frac{\Delta S^{o}}{R}\right)-\left(\frac{\Delta H^{o}}{R}\right)\left(\frac{1}{T}\right)$

The values of $\Delta H^{\circ}$ and $\Delta S^{\circ}$ were estimated from the slope and intercept of the plot of $\ln K_{\mathrm{L}}$ versus $1 / T$ (figure not shown).

From Table 7, it could be seen that $\Delta G^{\circ}$ values decreased with increase in temperature, which was an indication of the spontaneous nature of the process. The positive $\Delta H^{\circ}$ value shows that the process was endothermic, while the positive $\Delta S^{\circ}$ value indicates increased randomness in the molecular movement between the solid-liquid interphase. The value of the $\Delta H^{\circ}$, found to be less than $40 \mathrm{~kJ} / \mathrm{mol}$, indicates that 
the process was physisorption. This was in agreement with that obtained by Debnath and Ghosh (2008) for the study of "kinetics, isotherm and thermodynamics for $\mathrm{Cr}$ (III) and $\mathrm{Cr}(\mathrm{VI})$ adsorption from aqueous solutions by crystalline hydrous titanium oxide."

\section{Conclusion}

The eco-friendly approach for PWW coagulation-flocculation was successfully conducted using BEC under stated experimental conditions. The instrumental analyses results reveal the functionality of the coagulant sample while the jar test operation showed that the removal efficiency of TDSP was greatly influenced by the effects of process parameters (coagulant dosage, effluent $\mathrm{pH}$, coagulation temperature and settling time). Maximum removal efficiency of $96.50 \%$ was achieved at the optimal variable conditions of $5 \mathrm{~g} / \mathrm{L}$ coagulant dosage, $\mathrm{pH}$ of 8 and $35{ }^{\circ} \mathrm{C}$ coagulation temperature. The adsorptive studies revealed that the process followed a pseudo-second-order kinetic model with intra-particle diffusion found to be the rate-determining step. Langmuir isotherm model best fitted the equilibrium data. Thermodynamic analysis indicates that the process was spontaneous and endothermic. The results show the usability of BEC and demonstrated significant dominance of adsorption regime on the coagulation treatment of PPW using BEC.

Acknowledgements The authors wish to acknowledge and thank the following organizations for their assistance toward the completion of this work: Chemical Engineering Department, Nnamdi Azikiwe University Awka, Nigeria; Central Leather Research Institute, Chennai, India; India Institute of Chemical Technology, India; India National Science Academy/Centre for International Cooperation in Science, India; and Water Resources Center, Texas Tech University, Lubbock, TX, USA.

Open Access This article is distributed under the terms of the Creative Commons Attribution 4.0 International License (http://creativeco mmons.org/licenses/by/4.0/), which permits unrestricted use, distribution, and reproduction in any medium, provided you give appropriate credit to the original author(s) and the source, provide a link to the Creative Commons license, and indicate if changes were made.

\section{References}

Abdulsahib HT, Taobi AH, Hashim SS (2015) A novel coagulant based on lignin and tannin for bentonite removal from water. IJAR $3(2): 426-442$

Aboulhassan MA, Souabi S, Yaacoubi A, Baudu M (2014) Treatment of paint manufacturing wastewater by the combination of chemical and biological process. IJSET 3(5):1747-1758

Adebowale YA, Adebowale KA (2007) Evaluation of the gelation characteristics of mucuna bean flour and protein isolate. Electron $\mathrm{J}$ Environ Agric Food Chem 6:2243-2262
Al-Rasheed RA (2005) Water treatment by heterogeneous photocatalysis: an review. In: Proceedings of the 4th SWCC acquired experience symposium, Jeddah, Saudi Arabia

AFIA (2011) Afia-Laboratory methods manual; a reference manual of standard methods for the analysis of fodder (Australian fodder industry association Ltd) version 7, Sept 2011

Amirtharajah A, Mills MK (1982) Rapid-mix design for mechanisms of alum coagulation. J Am Water Works Assoc 74(4):210-216

Ani JU, Menkiti MC, Onukwuli OD (2011) Coagulation-flocculation performance of snail shell biomass for wastewater purification. N Y J 4(2):81-90

AOAC (2012) Official methods of analysis of Association of Analytical Chemists International. 19th edn. AOAC International, Gaithersburg, MD, USA, AOAC SMPR 2011.003

APHA (2012) Renowned "standard methods for the examination of water and wastewater, 22nd edn. Washington DC (202) 777-2509 [jointly published by the American public health association (APHA), the American water works association (AWWA) and the water environment federation (WEF)]

Assaad E, Azzouz A, Nistor D, Ursu AV, Sajin T, Miron DN, Monette F, Niquette P, Hausler R (2007) Metal removal through synergic coagulation-flocculation using an optimized chitosan-montmorillonite system. Appl Clay Sci 37:258-274

Aviara NA, Ibrahim EU, Onuoha LN (2014) Physical properties of Brachystegia eurycoma seeds as affected by moisture content. Int J Agric Biol Eng 7(1):84-93

Boehm HP (1994) Chemical identification of surface groups. In: Eley DD, Prines H, Weisz PB (eds) Advances in catalysis, vol 16. Academic Press, New York, pp 179-287

CCME (2008) Canada-wide strategy for management of municipal wastewater effluent. Technical report 3: standard method and contracting provisions for the environmental risk assessment. Canada council of minister of environment (CCME), June 2008

Chong CK, Xing J, Phillips DL, Corke H (2001) Development of NMR and Raman spectroscopic methods for the determination of the degree of substitution of maleate in modified starches. J Agric Food Chem 49:2702-2708

Choudhary M, Neogi S (2017) A natural coagulant protein from Moringa oleifera: isolation, characterization and potential use for water treatment. Mater Res Sci. https://doi.org/10.1088/2053$1591 / 998 \mathrm{~b} 8 \mathrm{c}$

da Silva FL, Barbosa DA, de Paula MH, Romualdo LL, Andrade SL (2016) Treatment of paint manufacturing wastewater by coagulation/electrochemical methods: proposals for disposal and/or reuse of treated water. Water Res. https://doi.org/10.1016/j.watre s.2016.05.006

Debnath S, Ghosh UC (2008) Kinetics, Isotherm and thermodynamics for $\mathrm{Cr}(\mathrm{III})$ and $\mathrm{Cr}(\mathrm{VI})$ adsorption from aqueous solutions by crystalline hydrous titanium oxide. J Chem Thermodyn 40:67-77

Diaz JJF, Quiroz JT, Manrique OP (2018) Extraction and efficiency of chitosan from shrimp exoskeleton as coagulant for lentic water bodies. Int J Appl Eng Res. 13(2):1060-1067. ISSN: 0973-4562

Diterlizzi SD (1994) Introduction to coagulation and flocculation of wastewater. Environmental System Project, USA

Dupuy N, Wojciechowski C, Ta CD, Huvenne JP, Legrand P (1997) Mid-infrared spectroscopy and chemometrics in corn starch classification. J Mol Struct 410:551-554

Ezeagu IE, Metges CC, Proll J, Petzke KJ, Akinsoyinu AO (2006) Chemical composition and nutritive value of some wild gathered tropical plant seeds. Deutscher Akademischer Austaischdienst, German Institute for Human Nutrition, Bonn, pp 3-4

Foo KY, Hameed BH (2010) Insights into the modeling of adsorption isotherm systems. Rev Chem Eng J 156:2-10

Freese SD, Trollip DL, Noziac DJ (2003) Manual for testing of water and wastewater treatment chemicals. Pietermaritzburg 3200, WRC report no. k5/1184 ISBN 
Gill P, Moghadam T, Ranjbar B (2010) Differential scanning calorimetry techniques: applications in biology and nanoscience. $\mathrm{J}$ Biomol Technol 21(4):167-193

Goldberg S (2005) Equations and models describing adsorption processes in soils. Soil science society of America, 677 S. Segoe Road, Madison, WI 53711, USA. Chemical processes in soils. SSSA book series, no. 8

Ikegwu OJ, Okechukwu PE, Ekumankama EO (2010) Physico-chemical and pasting characteristics of floor and starch from achi (Brachystegia eurycoma) seeds. J Food Technol 8(2):58-66

Jatto EO, Asia IO, Egbon EE, Otutu JO, Chukwuedo ME, Ewansiha CJ (2010) Treatment of wastewater from food industry using snail shell. Acad Arena 2(1):32-36

Klimiuk K, Filipkowska U, Korzeniowska A (1999) Effects of pH and coagulant dosage on effectiveness of coagulation of reactive dyes from model wastewater by polyaluminium chloride. Pol J Environ Stud 8(2):73-79

Kumar MM, Karthikeyan R, Anbalagan K, Bhanushali MN (2016) Coagulation process for tannery industry effluent treatment using Moringa oleifera seeds protein: kinetic study, $\mathrm{pH}$ effluent on floc characteristics and design of a thickener unit. Sep Sci Technol. https://doi.org/10.1080/01496395.2016.1190378

Kyzas GZ, Delitanni EA (2015) Modified activated carbons from potato peels as green environmental-friendly adsorbents for the treatment of pharmaceutical effluents. Chem Eng Res Des 97:135-144

Leclerc DF (2000) Fourier-transform infrared spectroscopy in the pulp and paper Industry. In: Meyers RA (ed) Encyclopedia of analytical chemistry, vol 10. Wiley, Chichester, pp 8361-8388

Madukasi EI, Ajuebor FN, Ojo B, Meadows AB (2009) Pollution removal from paint effluents using modified clay minerals. J Ind Res Technol 2(1):49-55

Maurya S, Daverey A (2018) Evaluation of plant-based natural coagulants for municipal wastewater treatment. Biotech. https://doi. org/10.1007/s13205-018-1103-8

Menkiti MC, Onyechi CA, Onukwuli OD (2011) Evaluation of perikinetics compliance for the coag-flocculation of brewery effluent by Brachystegia eurycoma seed extract. Int J Multidiscip Sci Eng 2:73-80

Menkiti MC, Aneke MC, Ejikeme PM, Onukwuli OD (2014) Adsorptive treatment of brewery effluent using activated cheysophyllum albidium seed shell. Springer Plus 3:213

Mohammed SJ, Husain IAF, Kabashi NA, Abdullah N (2012) Multiple inputs artificial neural network model for the prediction of wastewater treatment plant performance. Aust J Basic Appl Sci 6 (1):62-69. ISSN 1991-8178

Muruganandam L, Kumar MPS, Jena A, Gulla S, Godhwani B (2017) Treatment of wastewater by coagulation and flocculation using biomaterials. IOP Conf Ser Mater Sci Eng 263:032006

Narayana SK (2012) Development of models for dye removal process using response surface methodology and artificial neural networks. Int J Gen Eng Technol 1

Ndukwu MC (2009) Determination of selected physical properties of Brachystegia eurycoma seeds. Res Agric Eng 55(4):165-169

NESREA: National Environmental Standard and Regulations Enforcement agency (2005) Policy guidelines and standard for environmental control in Nigeria. FMENV, Abuja Nigeria
Ramani K, Jain SD, Mandal AB, Sekeran G (2012) Microbial induced lipoprotein biosurfactant from slaughterhouse lipid waste and its application to the removal of metal ions from aqueous solution. Colloids Surf B Biointerfaces 97:254-263

Roussy J, van Vooren M, Guibal E (2004) Chitosan for the coagulation and flocculation of mineral colloids. J Dispers Sci Technol 25(5):663-677

Santos AFS, Paiva PMG, Teixeira JAC, Brito AG, Coelho CBB, Nogueira R (2012) Coagulant properties of Moringa oleifera protein prepations: application to humic acid removal. Environ Technol 33(1):69-75

Simate GS, Iyuke SU, Ndlovu S, Heydenrych M (2012) The heterogenous coagulation and flocculation of brewery wastewater using carbon nanotubes. J Water Res 46:1185-1197

Suidan MT (1998) Coagulation and flocculation; environmental engineering unit operations and unit process laboratory manual, 4th edn. Association of Environmental Eng. Professors, Canada

Sutherland JP (2005) Process for preparing coagulants for water treatment. United States Patent, 6890565

Thiruganansambandham K, Sivakumar V (2014) Removal of ecotoxicological matters from tannery wastewater using electrocoagulation reactor: modelling and optimization. Desalin Water Treat. https://doi.org/10.1080/19443994.2014.989915

Tzoupanos ND, Zoubolis AI (2008) Coagulation-flocculation processes in water/wastewater treatment: the application of new generation of chemical reagents. In: 6th IASME/WSEAS international conference on heat transfer, thermal engineering and environment (THE'08) Rhodes, Greece, 20-22 Aug 2008

Vazquez G, Alvarez JG, Freire S, Moreno ML, Antorrena G (2002) Removal of cadmium and mercury ions from aqueous solution by sorption on treated Pinus pinaster bark: kinetics and isotherm. Bioresour Technol 82(3):247-251

Vijayaraghavan G, Sivakumar T, Kumar AV (2011) Application of plant based coagulants for wastewater treatment. Int J Adv Eng Res Stud 1:188-192

Vyazovkin S (2012) Thermogravimetric analysis, characterization of materials, 2nd edn. Wiley, USA, pp 1-12

Wei J, Gao B, Yue Q, Wang Y, Li W, Zhu X (2009) Comparison of coagulation behavior and floc structure characteristic of different polyferric-cationic polymer dual-coagulants in humic acid solution. Water Res 43:724-732

Wennie S, Wu TY, Siang-Piao C (2014) Standard methods for wastewater treatment. J Ind Crop Prod 61:317-324

Yin CY (2010) Emerging usage of plant-based coagulants for water and wastewater treatment. Process Biochem 45:1437-1444

Zeng Y, Park J (2009) Characterization and coagulation performance of a novel inorganic polymer coagulant-poly-zinc-silicate-sulfate. Colloids and Surf A 334:147

Publisher's Note Springer Nature remains neutral with regard to jurisdictional claims in published maps and institutional affiliations. 